\title{
Macroeconomic determinants of remittances to India
}

\author{
P. Jijin ${ }^{1} \cdot$ Alok Kumar Mishra ${ }^{2} \cdot$ M. Nithin ${ }^{3}$
}

Received: 26 May 2020 / Accepted: 25 August 2021 / Published online: 1 September 2021

(C) The Author(s), under exclusive licence to Springer Science+Business Media, LLC, part of Springer Nature 2021

\begin{abstract}
Migration and remittances have always been an exciting arena of research for economists around the globe. Remittance flows have evolved as a significant economic variable over the past decade. In several developing countries, remittances exceed the other capital inflows and value of total exports. Thus, it is widely recognised as a potential funding source for economic development in emerging economies. The inflow of remittances to India has increased tremendously in the recent past making the country the highest recipient of remittances across the globe. Remittances are an essential component that contributes to narrowing the Current Account Deficit and has always been a stable constituent of the Balance of Payment. This paper is an attempt to explore the vital macroeconomic variables which determine the remittance flows to India. Notably, we enquire into the dominant motives of remittances in the Indian context. We employ an ARDL approach to cointegration to identify the macroeconomic determinants of remittances and find those crucial variables such as exchange rate, oil price, and domestic GDP substantially impact the flow of remittances. The results also indicate that the migrants are more vulnerable to the oil price shocks in host countries. The overall findings of our study are that (1) remittances are not countercyclical in the Indian context (2) remittances are subject to weak investment motive as opposed to the altruistic motive.
\end{abstract}

Keywords Remittances - Altruistic motive - Investment motive · ARDL . Cointegration

JEL Classification F24 $\cdot$ F22 $\cdot$ E20 $\cdot$ C32

Alok Kumar Mishra

misalok@gmail.com

Extended author information available on the last page of the article 


\section{Introduction}

Remittances have emerged as a significant contributor to the development of many emerging economies over the last few decades. Remittances are fundamentally a transfer of money as payment or gift from emigrants to their families or other individuals in their home country. It primarily represents "household income from foreign economies, arising mainly from the temporary or permanent movement of people to those economies" (IMF 2009). The remittances are the second-largest foreign currency source in the world economy, and it forms a significant part of the Balance of Payment (BoP) account in most developing countries. In several emerging economies, remittances exceed the value of total export as well as the capital flows such as a Foreign Portfolio Investment (FPI), Foreign Direct Investment (FDI), and Official Development Assistance (ODA) [World Bank, 2018]. In 2019, total global remittances exceeded $\$ 700$ billion. The share of Low- and Middle-Income Countries (LMICs) constitutes around \$550 billion (World Bank 2021), nearly three times the foreign aid inflows.

The World Bank (2021) reports that the remittances to LMICs declined by 1.6 percent in 2020 owing to the Covid-19 crisis. However, the decline in remittances is far lower than the decline in FDI inflows (11\%, World Bank 2021). Further, this fall is lesser than the decline recorded during the global financial crisis in 2009. It signifies the resilient behaviour of remittances during a crisis. The only other instance of a drop in remittances in recent history was during 2015-2016 when the remittances to LMICs plummeted by $1.3 \%$. It may be due to the weakening of the US dollar and the financial tightening of host countries resulting from the oil price crash. At the same time, the employment opportunities for Indian migrants were also limited by the stringent nationalisation policies of Gulf Cooperation Council (GCC) countries, especially Saudi Arabia (World Bank 2018,2021). Given the expected global economic recovery from the pandemic, World Bank (2021) projects the rebound of remittances to $\$ 553$ billion (an increase of $2.6 \%$ ) to the developing countries in 2021.

In the literature, it is well recognised that a stable flow of remittances undoubtedly has a substantial role in developing countries. Based on a quantitative survey of the literature, Cazachevici et al. (2020) find that the mean effect of remittances on economic growth is positive but economically small. Remittances are a catalyst for financial sector development, through its significant contribution to the credit market development and the outreach of financial services (Giuliano and Ruiz-Arranz 2009; Aggarwal et al. 2011; Cooray 2012; Anzoategui et al. 2014; Fromentin 2017; Bangake and Eggoh 2020). In low- and middle-income countries, remittances have a positive long-run impact on both household credit and firm credit (Fromentin and Leon 2019). It also mitigates growth volatility, especially in countries with high financial development status (Chami et al. 2008; Ahamada and Coulibaly 2011). Many studies also observe the capacity of remittances in both physical and human capital accumulation, and poverty and inequality reduction, as it directly impacts income distribution (Imai et al. 2014; Jouini 2015; Bang et al. 2016; Akobeng 2016; Ahmed et al. 2018; Akter 2018). The 
welfare gains are high when the internal distribution of remittances is skewed towards entrepreneurs (Bahadir et al. 2018). However, few studies argue that the remittances-growth effect is country-specific, where institutional and development factors and cultural idiosyncrasies have a profound role in determining the outcome of remittances (Kadozi 2019; Piteli et al. 2019).

Since India is the largest remittances receiver, one cannot undermine the significance of remittances in its development process. Several macroeconomic studies reveal that remittances contribute to India's current account deficit by financing a large part of the balance of the trade deficit. Moreover, remittances have positive implications for the overall output growth through their direct utilisation for consumption and investment (Gupta 2006; Pande 2018; Singh and Hari 2011; Noushad et al. 2020). However, little attention has been paid to explore the macroeconomic determinants of remittances in the Indian context. Understanding the key factors affecting remittances at the macro-level may help design policies to ensure uninterrupted inflow. Therefore, the study contributes to the literature by identifying the macroeconomic determinants of migrants' transfers to India. To this end, we use the ARDL bound testing approach [following Pesaran and Shin (1995) and Pesaran et al. (2001)] to identify the presence of a long-run equilibrium relationship.

The key findings of the study suggest that exchange rate, oil price, and domestic GDP have a substantial impact on India's inward remittances. The study also finds that pure altruism does not dominate the underlying motive for remittances to India. Moreover, the inflows are found to be procyclical. Remittances have a long-run equilibrium association with the exchange rate, oil price, and domestic GDP, and any shock to these variables quickly converges to the long-run path. The Indian migrants (mostly in gulf countries) are more vulnerable to the oil price shocks. Therefore, we suggest that the policies be framed to protect the vulnerable migrants from the relentless external economic shocks. Providing them with investment opportunities in their country of origin may ensure a stable inflow of remittances. Also, protective policies are the need of the hour against the backdrop of the Covid-19 crisis.

The rest of the paper is organised as follows. The trajectory of remittances to India is briefly outlined in section two. The third section briefly explores the current literature on the macroeconomic determinants of remittances. The fourth section describes the data used and the methodology employed to discover the link between remittances and macroeconomic variables in the Indian context. The fifth section presents the empirical results and discussion, followed by a conclusion in the sixth section.

\section{Remittances to India: some highlighted facts}

Since 1991, remittances have evolved as a prominent component of the current account of Balance of Payment (BoP) in India (Gupta 2006; Pande 2018) ${ }^{1}$. An initial surge in remittances observed in the 1970s and 1980s (sprouted from the oil price boom in the Middle East) benefited India's foreign exchange reserves (Pande 2018). This growth has sped up in the post-reform period following the information technology revolution and exhibited steady progress up to 2003. 
Table 1 Remittance Inflows to India (US\$ Billion). Source: World Bank

\begin{tabular}{llllllllll}
\hline Year & 1990 & 1995 & 2000 & 2005 & 2010 & 2014 & 2016 & 2018 & 2019 \\
\hline Personal remittances & 2.39 & 6.22 & 12.85 & 22.13 & 53.48 & 70.39 & 62.74 & 78.79 & 83.13 \\
\hline
\end{tabular}

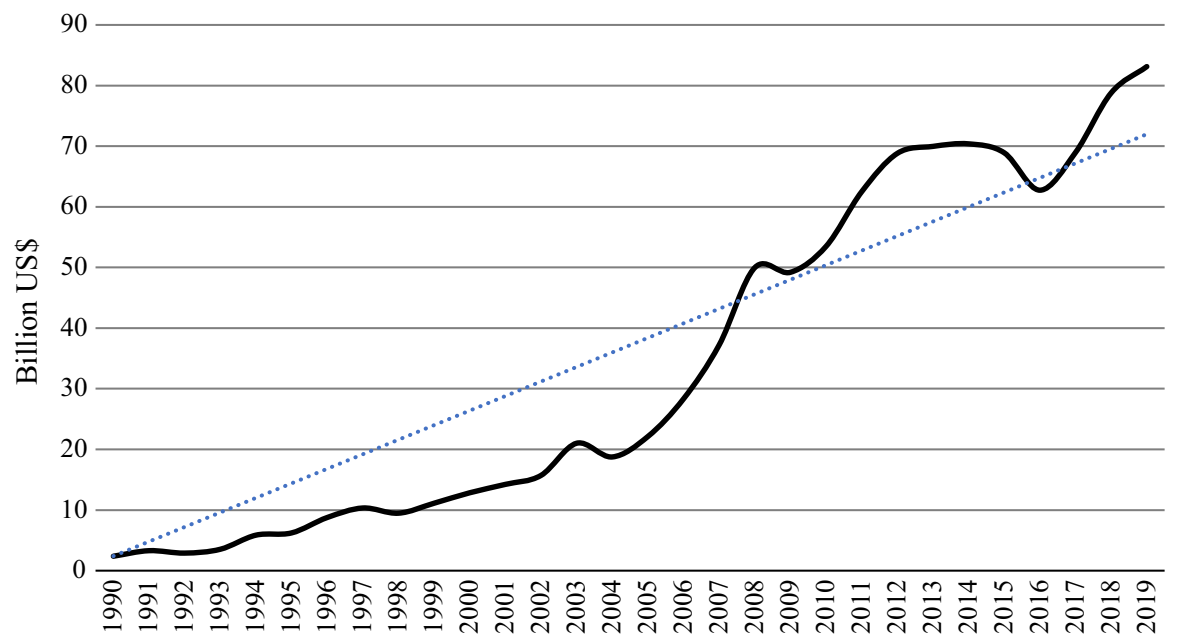

Fig. 1 Remittances to India. Source: KNOMAD, World Bank

Subsequently, India emerged as a top remittance recipient in the world. For example, the reported remittances from overseas Indians are a modest $\$ 2.39$ billion in 1990 and have grown to $\$ 53.48$ billion in 2010 and $\$ 83.13$ billion in 2019 (see Table 1). The increase during the 1990s is mainly attributed to the shift of emigration from developing to the developed countries like the USA, Canada, and Australia and the increasing share of highly skilled workers (Pande 2018). Moreover, financial sector reforms and the transaction cost reduction might have likewise led the remittances towards the formal channels (Giuliano and Ruiz-Arranz 2009).

However, the growth of remittances in the 1990s pales compared with its abrupt growth to $\$ 50$ billion in 2008 from a below $\$ 20$ billion in 2004 . The increased globalisation resulting from the liberalised policies of the government, growing efficiency among commercial banks and money transfer units, the promising profile of recent emigrants could trigger the healthy inflow of remittances to India. The remittances were resilient during the initial period of the global recession of 2008, as Fig. 1 indicates. All the same, it was accompanied by a slight decline and recovered immediately to the above-trend level. The remittances were at their historical record of approximately $\$ 70$ billion in 2014. Nevertheless, it declined to $\$ 62$ billion in 2016. The fall is attributed to the anti-immigration sentiments and nationalisation policies, especially in the Gulf region, which is the foremost destination for the Indian diaspora (World Bank 2018; Pandikasala et al. 2020). 
It has been observed that migrants' transfers are a stable form of foreign inflows to India as its volatility is lesser than that of other inflows like FPI and FDI (Pandikasala et al. 2020). The enormous flow of remittances has helped India offset the detrimental impact of the trade deficit on the current account deficit (Gupta 2006). Thus, it is indispensable to give ample attention to the host and home country factors that drive the remittance inflows to India.

\section{Review of literature}

The theoretical debate on remittances was triggered in the 1980s, especially after the path-breaking paper by Lucas and Stark in $1985 .^{2}$ Since then, the empirical studies rest upon the two motives behind remittances: altruism and self-interest. 'Pure altruism' as in Lucas and Stark (1985) is a simple model in which the migrant's utility is derived from the utility of the dependent households. As per this theory, remittances should increase as the recipient household's income decreases. More precisely, a one-unit increase in the income of the migrant, coupled with a one-unit drop in the recipient household's income, should raise the remitted amount precisely by the same unit. Another motive, the self-interest emerges from the migrant's aspiration to accumulate assets at home [see Rapoport and Docquier (2006) for a detailed survey of the theory on motives to remit].

By and large, remittances are either driven by altruistic or self-interest motives. In the former case, remittances are countercyclical, and in the latter, they are procyclical (De et al. 2019). Altruistically motivated remittances smoothen the consumption pattern of recipient households. It also serves as insurance against any adverse events in the home country (Stark 1995; Gubert, 2002). Given the core concept of the motive of remittances, macroeconomic studies attempt to understand the underlying factors that drive remittances, especially to the developing countries. ${ }^{3}$

De et al. (2019) say that "if the motivations are altruistic, remittances will increase when the receiving economy is in a downturn and vice versa. This would imply a negative relationship between remittances and recipient economy GDP resulting in counter-cyclicality." In the time of financial distress, remittances perform above the trend growth in developing countries. Remittances are resilient during the financial crisis, while other foreign inflows are weak (De et al. 2019). Bouhga-Hagbe (2004) finds that remittance flows are countercyclical to the episodes of declining output and employment in the home country. Anwar and Mughal (2012) argue that altruism is the most likely motive behind remittances sent by Pakistanis living abroad. Mughal and Ahmed (2014) also find the counter-cyclicality of remittances in India and Pakistan, while procyclical in Bangladesh and Sri Lanka. They argue that the size of remittances concerning domestic output determines its response to the business cycle fluctuations. If the remittances are countercyclical, it may mitigate the income fluctuations in the receiving country. Thus, the potentiality of remittances can be evaluated by their pattern during economic downturns.

However, De et al. (2019) find that remittances are acyclical in 80 percent of 109 countries (mainly developing and emerging market economies). Moreover, remittances appear to be procyclical in many high remittance-receiving countries. If the 
remittances are procyclical, it tends to amplify the output fluctuations in the home country (Chami et al. 2008). In an empirical study using a sample of 12 developing countries, Sayan (2006) also finds evidence against the counter-cyclicality of remittances. Lim and Morshed (2015), a study based on 122 developing countries, observes that the income contraction in home countries does not induce the migrants to remit more.

Past macroeconomic studies have incorporated several variables to deal with the debate over different motives of remittances. Those studies account for host and home country factors, like national income, unemployment, inflation, interest rates, exchange rate volatility, oil price movements, etc. Moreover, aspects like migrant stock, financial development, foreign exchange restrictions, and political risk also received significant attention in the literature on remittances.

The migrant stock is considered to be the prime determinant of remittances. There is a positive association between migrants' population and remittance flows (Kakhkharova et al. 2017). Freund and Spatafora (2008) show that an increase in migrant stock leads to a proportionate increase in foreign remittances in OECD countries. This relationship also holds in Turkey, which is unitary elastic (Elbadawi \& Rocha 1992).

Further, the economic condition of the source country and destination country of migrants is also an essential determinant of their income transfer. A more significant gap between the destination and source countries leads to more remittance inflows in middle-income countries (Yoshino et al. 2020). Remittances are closely associated with the economic activity in the host countries, with a positive affiliation to the income cycles (Elbadawi \& Rocha 1992; El-Sakka and McNabb 1999; Vacaflores 2018). Gupta (2006) and Jadhav (2003) also find the significant impact of the host country's economic condition on India's remittance receipts. However, Mughal and Ahmed (2014) find an acyclical behaviour of remittances to the external economic shocks, as skilled migrants at large in those regions are least affected by it. During the global recession of 2008, remittance inflows to the developing economies were plummeted, primarily due to the risen unemployment in the host economies. However, private transfers to India were resilient to the different episodes of financial crisis around the globe (Gupta 2006; Imai et al. 2014; Pandikasala et al. 2020).

A positive relationship with the interest rate variables suggests that the remittances are more attracted by the investment return (Aydas et al. 2005; Adams 2009). For example, Ojede et al. (2019) find that a substantial increase in the domestic interest rate compared to the foreign interest rate makes domestic assets more attractive to the emigrants from Uganda. On the other hand, a weak investment motive is also shown by the insignificant interest rate differential estimates (Schiopu and Siegfried 2006; Chami et al. 2008). The NRI deposits to India are affected by interest rate differences between home and host countries, while the inward remittances are not (Gordon and Gupta 2004; Gupta 2006).

Inflation discourages investment opportunities in the home country, adversely affecting remittances (Elbadawi and Rocha 1992; Aydas et al. 2005). Abbas et al. (2017), a Pakistan-based study, argue that an inverse relationship between remittances and inflation signifies less investment by migrants due to the unstable macroeconomic condition. Conversely, a positive relationship of remittances with inflation 
can be an indication of the altruistic motive. It is due to the extended support of migrants towards their families during a rise in the cost of living (El-Sakka and McNabb 1999).

The exchange rate also affects remittances as the sum of two opposite effects: wealth effect and substitution effect (Akçay and Karasoy 2019). A rise in the value of money earned in foreign currency increases the purchasing power of migrants in terms of domestic currency, thereby inducing the wealth effect among the receiving households. The migrants with investment motives exploit the exchange rate fluctuations and send more money to the home country to accumulate durable or fixed assets. This positive impact of domestic currency depreciation on remittances is found in Pakistan and India in the long-run (Akçay and Karasoy 2019; Abbas 2020). On the contrary, Ojede et al. (2019) point out that domestic currency depreciation reduces remittances to Uganda. When the dollar equivalent of debt incurred by emigrants during the initial period of migration decreases, they tend to repay the debt. In addition, domestic inflation caused by currency depreciation would prompt them to remit more.

The prevalence of exchange rate restriction shifts the remittance inflows from the formal channel to the informal channel. The migrants divert their remittances towards the black-market as the difference between the official and black-market rates widens, and they get an extra return. Thus, the exchange rate controls discourage formal remittances due to the black-market premium (El-Sakka and McNabb 1999; Elbadawi and Rocha 1992; Aydas et al. 2005). The black-market exchange rate premium significantly abates the formal remittances to Nigeria and Venezuela (World Bank 2017). Therefore, a flexible exchange rate policy may promote the inflow of remittances through formal channels.

A high sending cost can switch remittances towards the informal routes. Freund and Spatafora (2008) find that a 1 percent rise in transaction cost can reduce the recorded remittances by $14-23$ percent. The global average cost of sending remittances is recorded at 6.67 percent in 2020 , remarked as a progress towards the G20 commitment to reduce the transaction cost to 5 percent. However, it is significantly above the 3 percent target set in the United Nations 'Sustainable Development Goals (SDG)' (World Bank 2020). The migrants respond to the reductions in transaction costs by sending more remittances to their home countries.

The transaction cost in any economy is systematically related to its financial development status. A country with a better financial system brings more remittances (Aggarwal et al. 2011; Coulibaly 2015). Thus, informal channels will be less in the countries with a well-built financial system. However, the domestic credit-toGDP ratio, a financial depth indicator, negatively impacts India's remittance (Pandikasala et al. 2020). That points towards the substitutability of remittances with private credit for migrant households.

Apart from the factors mentioned above, several non-economic factors can also influence remittances. Political instability and other natural hazards go a long way in altering the regular inflow of remittances. For instance, the prevalence of democracy helps to receive more remittances for Pakistan (Abbas et al. 2017). Aydas et al. (2005) find that the political instability during the military regime in Turkey reduced its remittance inflows. During natural calamities, remittances play a supporting role 
(Yang and Choi 2007), indicating the altruistic motive. However, Lim and Morshed (2015), based on a large panel study, find that a fall in income caused by weather shocks or natural disasters does not induce the migrants to remit more. Moreover, Lueth and Ruiz-Arranz (2006) show that remittances are not associated with natural disasters in European and Asian countries. Similarly, Gupta (2006) finds an insignificant response of remittances to the periods of drought, geopolitical tensions, and political uncertainty in India.

The literature is not offering conclusive evidence for a universal cause and effect relationship between the remittances and macroeconomic variables. Therefore, the sign of the relationship of remittances with the rest of the macroeconomic variables is still ambiguous. The inconsistent results across the studies are commonly attributed to the remittances' varying degree of significance in the receiving countries (Mughal and Ahmed 2014). A country-specific study could effectively capture the response of remittances to macroeconomic fluctuations.

\section{Data, variable description, and methodology}

\subsection{Data}

Data used for this study are collected from the RBI data warehouse (Handbook of Statistics on the Indian economy), FRED (data bank of the Federal Reserve Bank of St. Louis), and Organisation for Economic Cooperation and Development (OECD) website. A comprehensive description of the variables is given in Table 2. We use quarterly time-series data of variables for the period from 1996: Q2 to 2019: Q4. The selection of the sample is based on the availability of data on the desired frequency. It is important to note that the previous studies on remittance have taken only annual data for estimation. This study enables us to discover the relationship among variables at a comparatively high-frequency level and helps build a robust model and capture better dynamics.

\subsection{Variables description and descriptive statistics}

We provide a brief description of the variables used for the study in Table 2 . Table 3 reports summary statistics of all the variables.

It can be observed from Table 3 that the mean and the standard deviation of domestic GDP (gdp) and US GDP (usg) is extremely high. Both the variables have higher dispersion compared to other variables. All the variables are positively skewed except US GDP. The coefficient of kurtosis is negative for all the variables except relative inflation and stock market differential indicates that a distribution is flat and has thin tails. This implies that the distribution is platykurtic. The positive coefficient of relative inflation and stock market differential follows a leptokurtic distribution with a higher peak and taller tails than a normal distribution.

Table 4 reports the correlation among the variables under the study. We observe that all the variables except stock market differential (smd) are significantly 


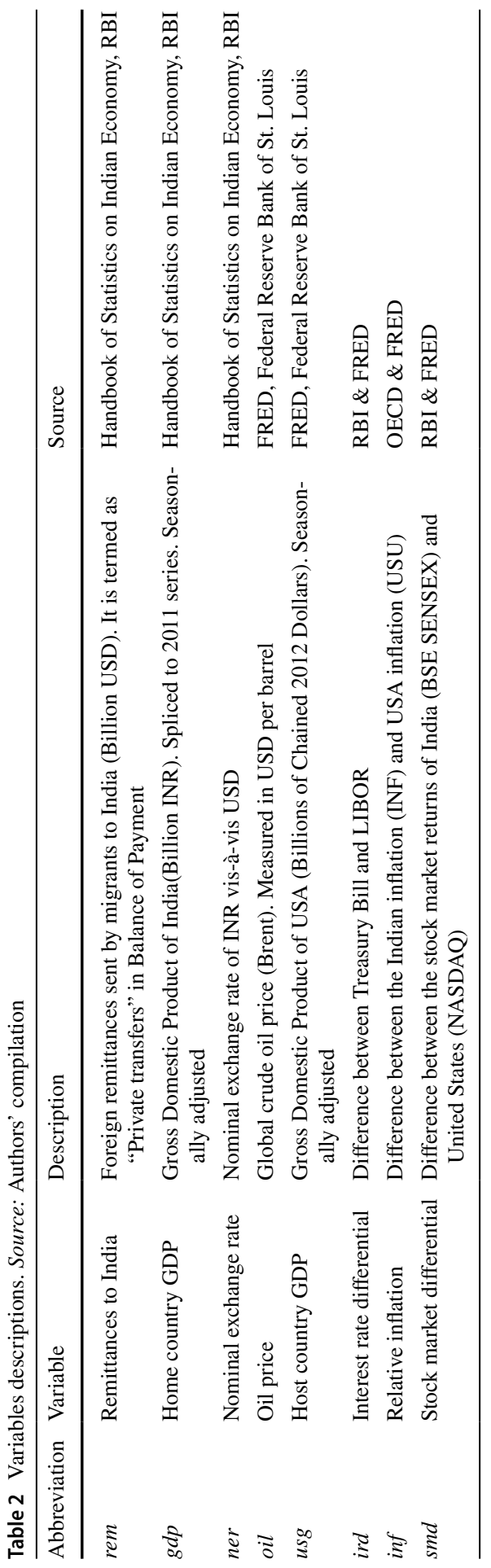


Table 3 Summary statistics. Source: Authors' estimation

\begin{tabular}{llllllllr}
\hline Variable & Mean & Median & Mode & Range & Variance & SD & Skewness & Kurtosis \\
\hline rem & 10.61 & 10.97 & 2.38 & 19.55 & 38.48 & 6.20 & 0.03 & -1.62 \\
gdp & $18,894.54$ & $17,379.72$ & 8097.37 & $28,669.31$ & $75,172,686.75$ & 8670.22 & 0.54 & -0.93 \\
ner & 50.83 & 46.63 & 35.64 & 36.43 & 104.01 & 10.20 & 0.66 & -0.83 \\
oil & 57.60 & 54.95 & 11.09 & 111.15 & 1047.65 & 32.37 & 0.43 & -0.94 \\
usg & $15,258.12$ & $15,436.04$ & $11,096.98$ & 8124.99 & $4,515,768.27$ & 2125.03 & -0.07 & -0.78 \\
ird & 4.31 & 3.69 & -0.50 & 10.80 & 5.25 & 2.29 & 0.47 & -0.45 \\
inf & 4.57 & 4.24 & -2.16 & 18.49 & 13.90 & 3.73 & 0.78 & 0.36 \\
smd & 0.004 & 0.003 & -0.24 & 0.53 & 0.01 & 0.09 & 0.11 & 0.87 \\
\hline
\end{tabular}

Table 4 Correlation matrix. Source: Authors' estimation

\begin{tabular}{|c|c|c|c|c|c|c|c|c|}
\hline & rem & $g d p$ & ner & oil & usg & ird & inf & smd \\
\hline rem & 1 & & & & & & & \\
\hline$g d p$ & $0.94 * * *$ & 1 & & & & & & \\
\hline ner & $0.79 * * *$ & $0.92 * * *$ & 1 & & & & & \\
\hline oil & $0.75^{* * *} *$ & $0.54 * * *$ & $0.30 * *$ & 1 & & & & \\
\hline usg & $0.92 * * *$ & $0.97 * * *$ & $0.87 * * *$ & $0.62 * * *$ & 1 & & & \\
\hline ird & $0.63 * * *$ & $0.50 * * *$ & $0.51 * * *$ & $0.59 * * *$ & $0.45^{* * *}$ & 1 & & \\
\hline $\inf$ & $0.25^{*}$ & 0.10 & -0.02 & $0.25^{*}$ & 0.01 & $0.29 * *$ & 1 & \\
\hline smd & -0.07 & -0.06 & -0.03 & -0.02 & 0.05 & $-0.21 *$ & $-0.23^{*}$ & 1 \\
\hline
\end{tabular}

. The asterisk signs $* * *, * *, *$ represent level of significance at $1 \%, 5 \%$ and $10 \%$, respectively

associated with our variables of interest. The high pairwise statistically significant correlation coefficient is found between domestic GDP and remittances; US GDP and remittances; nominal exchange rate and domestic GDP; host country GDP and home country GDP; nominal exchange rate and US GDP. The low negative correlation was found between the pair of relative inflation and interest rate differential; relative inflation and stock market return differential; and between inflation and stock market differential. We also observe that remittances are positively associated with all variables except stock market differential, which is negatively correlated and statistically insignificant. This result will help us in lateral analysis and estimation.

\subsection{Methodology}

To examine the key macroeconomic determinants of remittances to India, we employ the ARDL bounds testing approach to cointegration following Pesaran and Shin (1995) and Pesaran et al. (2001). The ARDL bounds testing approach allows for testing the presence of cointegration even in the presence of I (0) and I (1) variables, while the traditional methods, for example, Johannsen's method, require the variables to be of order I (1). Furthermore, the ARDL model is also free from the endogeneity issues arising from using the lags of the dependent 
variable as instruments. We estimate Eq. 1 to check for cointegration among the variables under the study.

$$
\Delta Y_{t}=\beta_{0}+\sum_{i=1}^{n} \beta_{i} \Delta Y_{t-i}+\sum_{j=1}^{n} \gamma_{j} \Delta X_{1 t-j}+\cdots+\sum_{k=1}^{n} \delta_{k} \Delta X_{n t-k}+\theta_{0} Y_{t-1}+\theta_{1} X_{1 t-1}+\cdots+\theta_{n} X_{n t-1}+\varepsilon_{t}
$$

$Y_{t}$ denotes the dependent variable in the above equations, which is remittances to India (rem), and $X_{t}$ represents a list of independent variables. The set of explanatory variables includes nominal exchange rate of rupee vis-à-vis US dollar (ner), global average oil price $(o i l)$, the interest rate premium ( $i r d)$, home country's gross domestic product $(g d p)$, host country GDP ( $u s g$ ), inflation differential (inf), and stock market differential $(s m d)$. The choice of variables is purely based on the extensive review of the literature.

We test for the null hypothesis of no-cointegration or the absence of long-run relationship, which is represented as $\theta_{0}=\gamma_{j}=0$ while the alternative hypothesis tests for $\theta_{0} \neq \gamma_{j} \neq 0$. The F-test associated with the hypothesis is non-standard, and the null hypothesis can be rejected if the calculated F-statistic is higher than the upper bound critical value. The null hypothesis cannot be rejected if the F-statistic is lower than the lower bound value. At the same time, the test is inconclusive in the event of F-statistic lying between the lower and upper bound values. Once cointegration among the variables is established, we estimate the error correction as given in Eq. 2.

$$
\Delta Y_{t}=\beta_{0}+\sum_{i=1}^{n} \beta_{i} \Delta Y_{t-i}+\sum_{j=1}^{n} \gamma_{j} \Delta X_{1 t-j}+\cdots+\sum_{k=1}^{n} \delta_{k} \Delta X_{n t-k}+\theta Z_{t-1}+\varepsilon_{t}
$$

where $Z_{t-1}=\left(Y_{t-1}-\alpha_{0}-\alpha_{1} X_{1 t-1} \cdots-\alpha_{n} X_{n t-1}\right)$.

The above form of the equation is then used to estimate the long-run multipliers.

\section{Empirical results and discussion}

\subsection{Stationarity tests}

Although the ARDL model does not require pre-testing for the presence of unit roots, unlike traditional models, it is necessary to ensure that none of the variables is integrated of order two [I (2)]. To this end, we use three popular tests viz. Dicky-Fuller GLS (DF-GLS), ${ }^{4}$ Philips-Peron (PP), and Kwiatkowski-Phillips-Schmidt-Shin (KPSS) to determine the order of integration of the variables. Both DF-GLS and PP tests assume a null hypothesis of the presence of unit roots (underlying series is non-stationary), while the KPSS tests assume a null hypothesis of stationarity. Table 5 reports the results of the tests.

The critical values for unit root tests (DFGLS, PP, and KPSS): 
Table 5 Stationarity tests (ADF, PP, and KPSS). Source: Authors' estimation

\begin{tabular}{|c|c|c|c|c|c|c|c|}
\hline \multirow[t]{2}{*}{ Variable } & \multicolumn{2}{|l|}{ DFGLS } & \multicolumn{2}{|l|}{ PP } & \multicolumn{2}{|l|}{ KPSS } & \multirow[t]{2}{*}{ Conclusion } \\
\hline & Level & 1 st dif & Level & 1st dif & Level & $1 \mathrm{st}$ dif & \\
\hline rem & -1.59 & $-5.00 * * *$ & -3.08 & $-16.58 * * *$ & $0.39 * * *$ & 0.06 & I (1) \\
\hline$g d p$ & -1.63 & $-3.62 * * *$ & -2.66 & $-9.64 * * *$ & $0.23 * * *$ & $0.12 *$ & I (1) \\
\hline oil & -1.90 & $-5.04^{* * *}$ & -1.71 & $-7.37 * * *$ & $0.43 * * *$ & 0.06 & I (1) \\
\hline ner & -1.52 & $-3.91 * * *$ & -1.91 & $-7.21 * * *$ & $0.35^{* * *}$ & 0.08 & I (1) \\
\hline usg & -1.41 & $-3.50 * *$ & -2.61 & $-6.68 * * *$ & $0.35 * * *$ & $0.17 * *$ & I (1) \\
\hline ird & -2.05 & -1.40 & -3.06 & $-12.02 * * *$ & $0.20 * *$ & 0.11 & I (1) \\
\hline inf & $-1.94 * *$ & $-5.11^{* * *}$ & $-3.07 * *$ & $-8.72 * * *$ & $0.18^{* *}$ & 0.04 & $\mathrm{I}(0)$ \\
\hline smd & $-2.76^{* * *}$ & $-2.16^{* *}$ & $-7.21 * * *$ & $-15.31 * * *$ & $0.24 * * *$ & 0.04 & $\mathrm{I}(0)$ \\
\hline
\end{tabular}

The asterisk signs $* * *, * *, *$ represent level of significance at $1 \%, 5 \%$ and $10 \%$, respectively

\begin{tabular}{llllllr}
\hline Significance level & \multicolumn{2}{l}{ DFGLS } & & PP & KPSS \\
\cline { 2 - 3 } & Intercept & Trend & & Intercept & Trend & \\
\hline $1 \%$ & -2.59 & -3.58 & & -3.501 & -4.058 & 0.216 \\
$5 \%$ & -1.94 & -3.03 & & -2.892 & -3.458 & 0.146 \\
$10 \%$ & -1.62 & -2.74 & & -2.583 & -3.154 & 0.119 \\
\hline
\end{tabular}

The stationarity test results indicate that all variables except inflation and stock market differential are non-stationary at levels or I (1), which is expected. The stationarity tests thus warrant that we employ the ARDL model as the variables are a mix of the I (0) and I (1) series.

\subsection{ARDL bounds testing for cointegration}

Having ensured none of the variables is integrated of order two, which is a pre-requisite for the ARDL model, we estimate Eq. 1 and test for the presence of cointegration or long-run relationship using the bounds testing approach. We estimate an ARDL model of the form $(1,0,0,0,1,1,1,0)$, and the lag selection is based on AIC criterion as ARDL models are sensitive to lag length to avoid endogeneity issues. We also use critical values provided by Kripfganz and Schneider (2018) as the critical values obtained are finite-sample and asymptotical as compared to the relative asymptotic critical values provided by Pesaran et al. (2001) and Narayan (2005). The results of bounds testing are reported in Table 6 .

The critical values of bounds test.

\begin{tabular}{|c|c|c|c|c|c|c|}
\hline \multirow[t]{2}{*}{ Tests } & \multicolumn{2}{|l|}{$10 \%$} & \multicolumn{2}{|l|}{$5 \%$} & \multicolumn{2}{|l|}{$1 \%$} \\
\hline & I (0) & I (1) & I (0) & I (1) & I (0) & I (1) \\
\hline F-test & 2.101 & 3.282 & 2.442 & 3.723 & 3.199 & 4.682 \\
\hline
\end{tabular}


Table 6 ARDL bounds test for cointegration. Source: Authors' estimation

\begin{tabular}{lllll}
\hline Models & Lag selection & F-stat & t-stat & Cointegration \\
\hline rem=f (ner, gdp, oil, usg, ird, inf, smd $)$ & $(1,0,0,0,1,1,1,0)$ & $6.54 * * *$ & $6.89 * * *$ & Yes \\
\hline
\end{tabular}

The asterisks (***) denote statistical significance at $1 \%$

\begin{tabular}{|c|c|c|c|c|c|c|}
\hline \multirow[t]{2}{*}{ Tests } & \multicolumn{2}{|l|}{$10 \%$} & \multicolumn{2}{|l|}{$5 \%$} & \multicolumn{2}{|l|}{$1 \%$} \\
\hline & I $(0)$ & I (1) & I $(0)$ & I (1) & I $(0)$ & I (1) \\
\hline t-test & -2.535 & -4.206 & -2.855 & -4.580 & -3.487 & -5.301 \\
\hline
\end{tabular}

Source: Kripfganz and Schneider (2018).

Table 6 delineates the result of the ARDL bound test for cointegration. It can be observed from the results that the F-statistic is clearly above the upper bound value of I (1) at all levels of significance. It indicates the rejection of the null hypothesis of no-cointegration. We conclude the presence of cointegration or long-run relationship among the variables.

\subsection{Long-run and short-run dynamics}

Once we establish cointegration between the variables, we estimate Eq. 2 to derive the long-run and short-run coefficients of the estimated model. Given the validity and reliability of the model, we discuss the short-run and the long-run relationship between remittances and their macroeconomic determinants.

Panel A of Table 7 reports the short-run dynamics of remittances with other variables. The estimated lagged error correction term (ect) is negative and highly significant at 0.1 percent. It confirms the existence of a substantial correction mechanism in the case of remittances whenever deviations from the long-run equilibrium occur. The speed of adjustment is relatively high, implying that 73 percent of the deviation dissipates within the following quarter. Therefore, the remittance-receiving households may find the fastest recovery from the disequilibrium on their regular income caused by macroeconomic shocks.

None of the variables is statistically significant in the short-run. However, many macroeconomic variables have a long-run association with remittances (see Panel B). The nominal exchange rate coefficient is highly significant, with a value of -0.68 . That means a one percent change in the exchange rate leads to a -0.68 percent reduction in remittances to India. This finding suggests substitution effect in remittance sending behaviour and agrees with the findings of Ojede et al. (2019), Akçay and Karasoy (2019), and Abbas (2020).

The proxy variables for host country economic conditions such as oil price and US GDP provide exciting insights. The oil price is positive and highly significant in the long-run, with a coefficient value of 0.28 . It concludes a 0.28 percent increase in remittances to India for a corresponding one percent increase in oil prices. This result is consistent with the earlier findings of Akçay and Karasoy (2019). However, 
Table 7 Estimated short-run and long-run coefficients of ARDL model. Source: Authors' estimation
Variables

Coefficients

A. Short-run coefficients

ect

$-0.73 * * *$

$(-6.89)$

$\mathrm{D}(u s g)$

0.06

(0.03)

$\mathrm{D}($ ird $)$

$-0.02$

$(-0.83)$

$\mathrm{D}($ inf $)$

$-0.01$

$(-0.57)$

con

$-5.07$

$(-1.10)$

B. Long-run coefficients

ner

$-0.68 *$

$(-1.94)$

$g d p$

$1.50 * * *$

(5.70)

oil

$0.28 * * *$

usg

$-0.42$

$(-0.45)$

ird

0.02

inf

smd

C. Diagnostic tests

R-squared

Adj.R-squared

0.35

AIC

$-107.01$

F-statistic

$5.52 * * *$

Ljung-Box autocorrelation test

1.17

Jarque-Bera normality test

12.78

ARCH LM-test

28.76

$2.79 * * *$

Stable

CUSUM test

The t-statistic is given in parenthesis; Asterisk sign(s) '*', '**' and ' $* * *$ ' denote the significance at $5 \%, 1 \%$ and $0.1 \%$ levels

the US GDP is not significant in the short-run or long-run, aligning with Mughal and Ahmed (2014). These results contradict that of Gupta (2006), who argues that remittances to India are influenced by the benign state of the US economy while not affected by the oil price movements. 
More than half of the Indian immigrant population is in GCC countries, primarily oil-producing economies (Noushad et al. 2020). Moreover, UAE is the primary source of remittances to India, followed by the USA and Saudi Arabia (Pandikasala et al. 2020). We should also notice that the emigrants to Gulf nations are mainly low-skilled workers, while most migrant workers to the USA are relatively skilled (Noushad et al. 2020). Therefore, the result implies that the Indian migrants (mostly in gulf countries) are more vulnerable to the oil price shocks. At the same time, migrant employees in the USA are not much exposed to the host country's economic shocks.

Moreover, the insignificant relative inflation shows that the inflationary pressure in both host and home countries does not impact remittances. We also find a positive impact of domestic GDP over remittances, contradicting Mughal and Ahmed (2014). The elasticity of remittances to the domestic GDP is 1.5 percent, significant at the 0.1 percent level. These results negate the general notion that remittances are countercyclical and altruistic. Therefore, we prove that remittances are not backed by pure altruism in the case of India. Further, a weak stock market and interest rate differentials indicate indifference of remittances to the stock market returns and interest rate premium.

Panel $\mathrm{C}$ reports the diagnostic test results of the ARDL model. The residuals of the model satisfy all conditions, including normality, no autocorrelation, and no heteroscedasticity. The R-squared and adjusted R-squared values are also reasonable with a significant F-statistic, a point towards the overall significance of the model. Finally, the stability of the model parameters is also tested with the cumulative sum of recursive residuals (CUSUM) test, ${ }^{5}$ proposed by Pesaran and Pesaran (1997). Furthermore, this indicates that the model parameters are stable. In Fig. 2, the curve remained between the two critical limits and confirms the stability of the model parameters.

\section{Conclusions}

The significant role of remittances in the development process of LMICs is broadly recognised in the present literature. Thus, the economic determinants of remittances are also widely explored by many cross-country and country-specific studies. However, less attention was given to check the association of remittances with

Fig. 2 CUSUM of recursive residuals of the model. Source: Authors' estimation

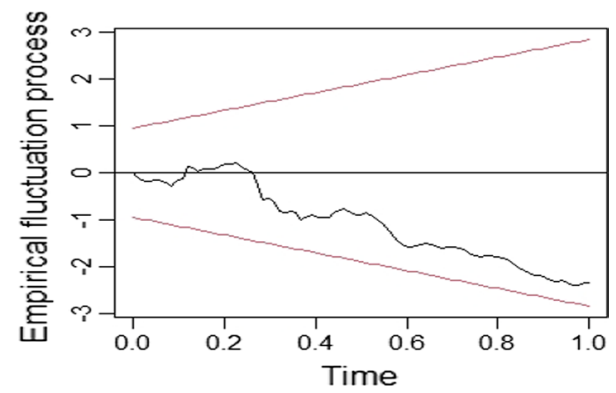


macroeconomic conditions in the Indian context. This study attempts to bridge this gap by adopting an ARDL approach to cointegration to find India's macroeconomic determinants of remittances. We use quarterly data spanning from 1996 to 2019 for estimation, while the earlier studies were mainly based on the annual data. We incorporate the major host country and home country variables in the model. The study succeeds in finding the significant macroeconomic variables that influence remittances, including nominal exchange rate, oil price, and domestic output. Each of these has a distinct and decisive impact on the remittance inflow. All the variables under consideration have only a long-run impact on remittances to India.

The higher error correction term in the ARDL model signifies that any deviations from the long-run equilibrium are corrected by around 73 percent in the next quarter. Therefore, downturns in remittances due to the macroeconomic shocks may not affect the receiving households longer. The depreciation of the Indian rupee results in a reduction in remittance inflows and points out remittances' substitution effect behaviour. Therefore, it rejects the wealth effect when migrants find the opportunity to take advantage of depreciation by sending more money.

Following the recent studies, we find that a rise in oil prices increases remittances to India. Since a larger share of migrants from India is in GCC countries, the oil price rise can increase their ability to send more money home. As another proxy for the state of the host country's economy, the US GDP does not impact remittances. We suppose that the low-skilled migrants of the Gulf countries are more exposed to the host country economic fluctuations than the skilled migrants in countries like the USA.

Most importantly, the domestic output has a strong positive impact on remittance inflows. Thus, our study finds that, in contradiction to the common conviction, remittances are not countercyclical. The remittances are unresponsive to the inflation differential. Therefore, we negate the general notion of the pure altruistic motive of remittances, which is not evident in the Indian macroeconomic context. In general, we supposedly assume a weak presence of investment motives for remittance to India. However, we do not have corroborating evidence, as the stock market return and interest rate premium are insignificant.

Therefore, appropriate government policies in home countries that offer better investment opportunities for emigrants can ensure the uninterrupted inflow of remittances. We also emphasise the vulnerability of low-skilled migrants who are exposed to economic shocks in host countries. It is more important to note as the Covid-19 has equally shaken all the migrant destinations. The macroeconomic instabilities caused by the pandemic would put the life of migrants at peril also in the post-Covid era. Further enquiry is required into the prospects of remittances in this scenario. Notwithstanding all these concerns, remittances offer a stable flow of income to the dependent households as it quickly gets over the disequilibrium caused by the macroeconomic disturbances.

The recorded migrants' transfers to India are categorised as "private transfers" under the current account of the BoP. However, NRI (Non-resident Indians) deposits in India are a subset of the capital account. Private transfers are one-sided transactions that do not have any quid pro quo. It includes direct inward remittances for household maintenance, personal gifts/donations to charitable or religious 
institutions, gold and silver brought through passenger baggage, repatriation of bank savings, and local withdrawals from Non-Resident Rupee Accounts (RBI, 2010).

The paper titled "Motivation to Remit: Evidence from Botswana" introduced the 'motives to remit' which are the driving forces of remittances, through a household level study in Botswana.

Remittances are altruistic and countercyclical (Chami et al. 2008; Frankel 2011; Bettin et al. 2017). In contrast, it can be procyclical and positively correlated with income (Sayan 2006; Giuliano and Ruiz-Arranz 2009). Moreover, it can also be driven by a mix of both motives (Lueth and Ruiz-Arranz 2006).

Its a modified Dickey-Fuller t-test proposed by Elliott et al. (1996). This test is known for its greater power than the previous versions of the augmented DickeyFuller (ADF) test.

The Cumulative Sum of Squares (CUSUMQ) test is complementary to the CUSUM test to the extent the CUSUM tests are not powerful enough to reject the null hypothesis of no structural change in small samples. Since we have a decent sample size for estimation, we proceed with the CUSUM test only.

\section{End Notes}

${ }^{1}$ The recorded migrants' transfers to India are categorised as "private transfers" under the current account of the BoP. However, NRI (Non-resident Indians) deposits in India are a subset of the capital account. Private transfers are one-sided transactions that do not have any quid pro quo. It includes direct inward remittances for household maintenance, personal gifts/ donations to charitable or religious institutions, gold and silver brought through passenger baggage, repatriation of bank savings, and local withdrawals from Non-Resident Rupee Accounts (RBI 2010).

${ }^{2}$ The paper titled "Motivation to Remit: Evidence from Botswana" introduced the 'motives to remit' which are the driving forces of remittances, through a household level study in Botswana.

${ }^{3}$ Remittances are altruistic and countercyclical (Chami et al. 2008; Frankel 2011; Bettin et al. 2017). In contrast, it can be procyclical and positively correlated with income (Sayan 2006; Giuliano and Ruiz-Arranz 2009). Moreover, it can also be driven by a mix of both motives (Lueth and Ruiz-Arranz 2006).

${ }^{4}$ Its a modified Dickey-Fuller t-test proposed by Elliott et al. (1996). This test is known for its greater power than the previous versions of the augmented DickeyFuller (ADF) test.

${ }^{5}$ The Cumulative Sum of Squares (CUSUMQ) test is complementary to the CUSUM test to the extent the CUSUM tests are not powerful enough to reject the null hypothesis of no structural change in small samples. Since we have a decent sample size for estimation, we proceed with the CUSUM test only.

\section{Declarations}

Conflict of interest The authors declare that they have no conflict of interest. 


\section{References}

Abbas S (2020) Impact of oil prices on remittances to Pakistan from GCC countries: evidence from panel asymmetric analysis. OPEC Energy Rev 44(2):205-223

Abbas F, Masood A, Sakhawat A (2017) What determine remittances to Pakistan? The role of macroeconomic, political and financial factors. J Policy Model 39(3):519-531

Adams RH Jr (2009) The determinants of international remittances in developing countries. World Dev 37(1):93-103

Aggarwal R, Demirgüç-Kunt A, Peria MSM (2011) Do remittances promote financial development? J Dev Econ 96(2):255-264

Ahamada I, Coulibaly D (2011) How does financial development influence the impact of remittances on growth volatility? Econ Model 28(6):2748-2760

Ahmed J, Mughal M, Martinez-Zarzoso I (2018) They earn and send; we spend: consumption patterns of Pakistani migrant households. Int J Soc Econ 45(7):1092-1108

Akçay S, Karasoy A (2019) The asymmetric impact of oil prices on remittances: evidence from India. OPEC Energy Rev 43(3):362-382

Akobeng E (2016) Out of inequality and poverty: Evidence for the effectiveness of remittances in Sub-Saharan Africa. Q Rev Econ Finance 60:207-223

Akter S (2018) Do remittances and foreign aid augment the gross savings: Bangladesh, India and Philippines perspective? Int Rev Econ 65(4):449-463

Anwar AI, Mughal MY (2012) Motives to remit: some microeconomic evidence from Pakistan. Econ Bull 32(1):574-585

Anzoategui D, Demirgüç-Kunt A, Pería MSM (2014) Remittances and financial inclusion: evidence from El Salvador. World Dev 54:338-349

Aydas OT, Neyapti B, Metin-Ozcan K (2005) Determinants of workers remittances: the case of Turkey. Emerg Mark Financ Trade 41(3):53-69

Bangake C, Eggoh J (2020) Financial development thresholds and the remittances growth Nexus. J Quant Econ 18(2):425-445

Bahadir B, Chatterjee S, Lebesmuehlbacher T (2018) The macroeconomic consequences of remittances. J Int Econ 111:214-232

Bang JT, Mitra A, Wunnava PV (2016) Do remittances improve income inequality? An instrumental variable quantile analysis of the Kenyan case. Econ Model 58:394-402

Bettin G, Presbitero AF, Spatafora NL (2017) Remittances and vulnerability in developing countries. World Bank Econ Rev 31(1):1-23

Bouhga-Hagbe J (2004) Altruism and workers' remittances: evidence from selected countries in the middle east and central Asia. IMF working paper 06/130, International Monetary Fund

Cazachevici A, Havranek T, Horvath R (2020) Remittances and economic growth: a meta-analysis. World Dev 134:105021

Chami R, Barajas A, Cosimano T, Fullenkamp C, Gapen M, Montiel P (2008) Macroeconomic consequences of remittance. Occasional paper, no. 259, International Monetary Fund

Cooray A (2012) Migrant remittances, financial sector development and the government ownership of banks: evidence from a group of non-OECD economies. J Int Financ Markets Inst Money 22(4):936-957

Coulibaly D (2015) Remittances and financial development in Sub-Saharan African countries: a system approach. Econ Model 45:249-258

De S, Islamaj E, Kose MA, Reza Yousefi S (2019) Remittances over the business cycle: theory and evidence. Econ Notes Rev Bank Finance Monetary Econ 48(3):12143

Elbadawi IA, Rocha RR (1992) Determinants of expatriate workers' remittances in North Africa and Europe. Working paper, no. 1038, World Bank

Elliott G, Rothenberg TJ, James H (1996) Efficient tests for an autoregressive unit root. Econometrica 64(4):813-836

El-Sakka MIT, McNabb R (1999) The macroeconomic determinants of emigrant remittances. World Dev 27(8):1493-1502

Frankel J (2011) Are bilateral remittances countercyclical? Open Econ Rev 22(1):1-16

Freund C, Spatafora N (2008) Remittances, transaction costs, and informality. J Dev Econ $86(2): 356-366$ 
Fromentin V (2017) The long-run and short-run impacts of remittances on financial development in developing countries. Q Rev Econ Finance 66:192-201

Fromentin V, Leon F (2019) Remittances and credit in developed and developing countries: a dynamic panel analysis. Res Int Bus Financ 48:310-320

Giuliano P, Ruiz-Arranz M (2009) Remittances, financial development, and growth. J Dev Econ 9(1):144-152

Gordon J, Gupta P (2004) Non-resident Deposits in India: in search of return? Econ Polit Wkly 39(37):4165-4174

Gupta P (2006) Macroeconomic determinants of remittances: evidence from India. Econ Pol Wkly 41(26):2769-2775

Imai KS, Gaiha R, Ali A, Kaicker N (2014) Remittances, growth and poverty: new evidence from Asian countries. J Policy Model 36(3):524-538

IMF (2009) Balance of payments and international investment position manual-sixth edition (BPM6). International Monetary Fund, Washington, DC

Jadhav N (2003) Maximising developmental benefits of migrant remittances: the Indian experience. In: International conference on migrant remittances, London, pp 9-10

Jouini J (2015) Economic growth and remittances in Tunisia: Bi-directional causal links. J Policy Model 37(2):355-373

Kadozi E (2019) Remittance inflows and economic growth in Rwanda. Res Global 1:100005

Kakhkharova J, Akimovb A, Rohde N (2017) Transaction costs and recorded remittances in the postSoviet economies: evidence from a new dataset on bilateral flows. Econ Model 60:98-107

Kripfganz S, Schneider DC (2018) ARDL: estimating autoregressive distributed lag and equilibrium correction models. In: Proceedings of the 2018 London Stata conference

Lim S, Morshed AKM (2015) International migration, migrant stock, and remittances: reexamining the motivations to remit. Q Rev Econ Finance 57:101-115

Lucas RE, Stark O (1985) Motivations to remit: evidence from Botswana. J Polit Econ 93(5):901-918

Lueth E, Ruiz-Arranz M (2006) A gravity model of workers 'remittances. IMF working paper 06/290

Mughal MY, Ahmed J (2014) Remittances and business cycles: comparison of South Asian countries. Int Econ J 28(4):513-541

Narayan PK (2005) The saving and investment nexus for China: evidence from cointegration tests. Appl Econ 37:1979-1990

Noushad AP, Parida JK, Raman RK (2020) Low-skilled emigration, remittances and economic development in India. Migrat Dev 2020:1-31

Ojede A, Lam E, Okot N (2019) Identifying macro-determinants of remittance flows to a developing country: the case of Uganda. J Int Trade Econ Dev 28(4):429-451

Pande A (2018) India's experience with remittances: a critical analysis. Round Table 107(1):33-43

Pandikasala J, Vyas I, Mani N (2020) Do financial development drive remittances? Empirical evidence from India. J Public Affair. https://doi.org/10.1002/pa.2269

Persan MH, Pesaran B (1997) Microfit 4.0: interactive econometric analysis. Oxford University Press, Oxford

Pesaran MH, Shin Y, Smith RJ (2001) Bounds testing approaches to the analysis of level relationships. J Appl Econom 16(3):289-326

Pesaran MH, Shin Y (1995) An autoregressive distributed lag modelling approach to cointegration analysis. Cambridge working papers in economics 9514, Faculty of Economics, University of Cambridge

Piteli EE, Buckley PJ, Kafouros M (2019) Do remittances to emerging countries improve their economic development? Understanding the contingent role of culture. J Int Manag 25(4):100675

Rapoport H, Docquier F (2006) The economics of migrants' remittances. Handb Econ Giving Altruism Reciprocity 2:1135-1198

Sayan S (2006) Business cycles and workers' remittances: how do migrant workers' respond to cyclical movements of GDP at home? IMF working paper 06/52

Schiopu IC, Siegfried N (2006) Determinants of workers' remittances: evidence from the European neighbouring region. Working paper series no. 688, European Central Bank

Singh SK, Hari KS (2011) International migration, remittances and its macroeconomic impact on Indian economy. IIMA

Stark O (1995) The sharing and distribution of the returns to migration in developing countries. Crossing Borders. Transmigration in the Asia Pacific. Singapore: Prentice-Hall, pp 101-106 
Vacaflores DE (2018) Beyond altruism and self-interest: the growing importance of external factors in the determination of remittances flowing to Latin America. Int Econ J 32(2):235-255

World Bank (2017) Migration and development brief 27. World Bank, Washington, DC, April

World Bank (2018) Migration and development brief 30. World Bank, Washington, DC, December

World Bank (2020) Remittance prices worldwide. Issue 34, World Bank, Washington, DC, June

World Bank (2021). Migration and development brief 34. World Bank, Washington, DC, May

Yang D, Choi H (2007) Are remittances insurance? Evidence from rainfall shocks in the Philippines. World Bank Econ Rev 21(2):219-248

Yoshino N, Taghizadeh-Hesary F, Otsuka M (2020) Determinants of international remittance inflow in Asia-Pacific middle-income countries. Econ Anal Policy 68:29-43

Publisher's Note Springer Nature remains neutral with regard to jurisdictional claims in published maps and institutional affiliations.

\section{Authors and Affiliations}

\section{P. Jijin ${ }^{1} \cdot$ Alok Kumar Mishra² ${ }^{2} \cdot$ M. Nithin ${ }^{3}$}

P. Jijin

jijinpandikasala@gmail.com

M. Nithin

write2nithinm@gmail.com

1 Madras Institute of Development Studies (MIDS), 79, II Main Road, Gandhi Nagar, Adyar, Chennai 600 020, India

2 School of Economics, University of Hyderabad, Prof. C.R. Rao Road, Gachibowli, Hyderabad 500046, India

3 Department of Humanities and Social Sciences, Indian Institute of Technology Kharagpur, Kharagpur, India 